Journal of Engineering Sciences, Assiut University, Vol. 37, No. 1, pp.63 -84, January 2009

\title{
INVESTIGATION OF CRACKS IN SELF COMPACTING CONCRETE BY USING ULTRASONIC PULSE VELOCITY
}

\author{
Ashraf M. Heniegal \\ Assistant prof., Civil Strut. Dept., Faculty of Industrial Education, Suez. \\ Canal University, Suez, Egypt
}

(Received January 26, 2009 Accepted February 11, 2009)

\begin{abstract}
This paper describes the reliability of Ultrasonic Pulse Velocity (UPV) method in detecting horizontal cracks and flaws inside self compacting concrete $(S C C)$ and also to know more about if ultrasonic pulse velocity effective for measuring horizontal cracks in SCC.

Thirty beams was prepared in order to study the results of this research, sixteen beams for crack examinations for indirect UPV method and eight beams for detecting compressive strengths of beams with horizontal construction joint by direct method of UPV and by fracture methods also. Horizontal cracks were simulated using lower acoustic impedance material (plastic sheet) inserted at a known distance while casting the specimens. Three mixes of SCC were designed in order to prepare a new calibration curves for ultrasonic pulse velocity for detecting the compressive strength of SCC with horizontal cracks.

Results indicated that horizontal cracks induced to SCC may be detected by UPV if the transducers were in limited distance depending on the position and direction of readings and also the position of the cracks. In addition, compressive strength of SCC with one and two horizontal cracks was detected and a new calibration curves were prepared for detecting compressive strength of SCC with horizontal cracks.

Results indicated that UPV is reliable for investigation the horizontal cracks and flaws of SCC in addition to the compressive strengths of the defected SCC which helps the investigators in repair works but with some limitations of the distances and positions of receiver and transmitter. Experimental results also indicated that taking care should be taken into consideration for construction joint erection of SCC where a reduction of compressive strength of SCC with a construction joints was reduced by (9-14\%) whereas the reduction was about (10-17\%) for cracked SCC.
\end{abstract}

KEYWORDS: Self compacting concrete (SCC); ultrasonic pulse velocity; horizontal cracks; construction joint; multiple reflections.

\section{INTRODUCTION}

One of the principal objectives of the development of NDT techniques is a reliable assessment of defects of concrete members even when they are accessible only from a single surface. Especially on reinforced concrete structures such inspections could in the past only be solved by means of radiography (for concrete thickness less than 0.6 $\mathrm{m}$ ) or by using more or less destructive methods. When some of the established 
methods used in other areas of materials testing are applied to concrete testing, certain difficulties are encountered as concrete is an inhomogeneous, porous building material. There are mainly three ways of non destructive testing using ultrasonic techniques viz. Impact echo method, Pulse echo method and Pulse velocity method [1].

Ultrasonic pulse velocity is used to determine the crack depths in concrete. The test instrument consists of a means of producing and introducing a pulse into the concrete (pulse generator and transmitter), a means of accurately measuring the time taken by the pulse to travel through the concrete. A pair of piezoelectric sensors is placed at opposite ends of the test member. In one of the sensors, electronic pulses are generated and the time it takes for the pulse to propagate through the concrete is measured by the other sensor. Knowing the distance traveled, propagation velocity is calculated and based on the velocity, condition of the concrete is determined. Depending on the locations of the sensors, the procedure is divided in to three categories: direct (sensors at opposite ends), indirect (sensors on the same sides), and semi-direct (sensors at right angles) transmission. Indirect measurement is used in this study to assess the crack location in concrete [2].

Ultrasonic testing can be used not only for concrete quality control but also for determining the presence of the cracks, in a very efficient and sufficiently accurate way, and for defining how deep they are $[3,4,5]$.

Concrete structures as many other engineering structures are subjected to deterioration that affect their integrity, stability and safety. Faced with the importance of the damages method on the structures, the current choice is directed towards the repair of existing structures rather than towards the demolition construction of new ones. But before any repair work being done, it is common practice to determine the causes of the deterioration so that successful repair can not be done. Many repair works fail because the exact cause of the deterioration was not adequately identified. This identification process comprises many methods including non destructive testing methods. Non destructive testing is usually undertaken as part of the detailed investigation to complement the other method. Sometimes, the conclusions of the investigation are based on these tests [6]. First developed steel, it has not been easy to transfer the NDT technology to the inspection of concrete. Because of the characteristics of reinforced concrete, the nondestructive testing (NDT) of concrete is more complex than NDT of metallic materials [7]. In order for the NDT to better achieve its role in structural assessment there must have agreed standard and guidelines on how to do the survey in the field and interpret the data obtained [8]. Unfortunately until now the choice of the best fitted technique for a specific case is not simple. The relevance of the measurements process not guaranteed, and the question of how to cope with measurement results and how to finally assess the structure properties remains unanswered [9].

Various NDT methods have been developed and applied in engineering with different degrees of success [10,11,12,13, and 14]. Over the years, Non Destructive Testing (NDT) methods based on seismic waves propagation have gained increased use and popularity. Current wave-based NDT methods such as ultrasonic pulse velocity, impact echo, and spectral analysis of surface waves (SASW) have been used for the in-situ evaluation of material properties. However, there are some limitations in each of these NDT methods when they are used individually. These limitations have not been fully studied and understood. For example, the ultrasonic pulse velocity 
(UPV) method is one of the most commonly used wave-based methods in NDT. Yet, its potential for assessing the quality of materials is limited because of the different variables that affect the relationship between strength and velocity. This may be the reason why a poor correlation between the wave propagation parameters determined from the standard pulse velocity test method (ASTM C597) and the field rutting was reported by the FHWA, NCHRP Report 465 [15]. Improved techniques for processing the output signals such as the spectral analysis of attenuation are necessary to complement the strength-velocity data.

The main objective of this paper is to present preliminary results of an experimental program carried out to address the current deficiencies of the UPV method limitations for detecting cracks in both NC and SCC to improve the reliability.

\section{EXPERIMENTAL PROGRAM}

A total of twenty four concrete beams which represented 6 groups with dimensions $150 \times 200 \times 800 \mathrm{~mm}$ and $150 \times 400 \times 800 \mathrm{~mm}$ were cast with a certain procedure in order to simulate the horizontal cracks with limited positions. First group of beams was 6 beams ( 3 beams with $200 \mathrm{~mm}$ depth and 3 beams with $400 \mathrm{~mm}$ depth) with induced plastic sheet of dimensions $150 \times 300 \mathrm{~mm}$ for the all groups in the mid-span with different positions from the reference top surface, $(70 \mathrm{~mm}, 100 \mathrm{~mm}$ and $130 \mathrm{~mm})$ for beams with $200 \mathrm{~mm}$ depth and $(100 \mathrm{~mm}, 200 \mathrm{~mm}$ and $300 \mathrm{~mm})$ for beams with $400 \mathrm{~mm}$ depth. The second group was 2 beams one of them was $200 \mathrm{~mm}$ height and the second was $400 \mathrm{~mm}$ height but the induced sheets were two layer in this group (70 $\mathrm{mm}$ and 13 $\mathrm{mm}$ ) for beam with $200 \mathrm{~mm}$ height and $(100 \mathrm{~mm}$ and $300 \mathrm{~mm}$ ) for beam with $200 \mathrm{~mm}$ height. Groups 3 and 4 were the same of groups 1 and 2 respectively but the sheets were induced in the edge of all beams. All four groups were examined for detecting crack depths by three procedures indicated as case 1 , case 2 and case three.

- Case 1: the transmitter fixed at $50 \mathrm{~mm}$ from edge of the beam surface and receiver moved $50 \mathrm{~mm}$ intervals up to the end $700 \mathrm{~mm}$ from transmitter.

- Case 2: the transmitter and receiver were positioned at the mid span of the beam surface at a distance $100 \mathrm{~mm}$ then the two poles moved away to the edge direction with $100 \mathrm{~mm}$ intervals up to $700 \mathrm{~mm}$.

- Case 3: the transmitter fixed at mid span of the beam surface and the receiver moved to the edge towards the induced crack with $50 \mathrm{~mm}$ intervals up $350 \mathrm{~mm}$.

Group 5 and 6 represented eight beams of dimensions 150x400x800 mm were prepared for detecting compressive strengths by direct method of UPV of both induced cracked beams with plastic sheet and also beams with the construction joint which had a time period 1 day between each separation. In order to estimate the fracture compressive strengths of these groups, beams of were cut by introducing a cut perpendicular to the axis of the beam using a diamond tipped concrete cutter to prepare eight prisms of cross section $150 \times 400 \mathrm{~mm}$ and $150 \mathrm{~mm}$ breadth included one or two layers. In addition 2 prisms (one and two layers) from beams of designed compressive strength $400 \mathrm{~kg} / \mathrm{cm}^{2}$ from groups (1-4) were prepared.

Group 5 included four beams represented the induced cracked beams with designed compressive strengths 300 and $500 \mathrm{~kg} / \mathrm{cm}^{2}$ (chosen in addition to the beams 
with $400 \mathrm{~kg} / \mathrm{cm}^{2}$ in groups (1-4) were induced with one and two plastic layers of breadth $150 \mathrm{~mm}$ and $300 \mathrm{~mm}$ length.

In addition, group 6 was as the same of group 5 but with a horizontal construction joint along the length of the beams instead of the plastic sheets in order to simulate the nature of separation of SCC if it cast in multi layers. All eight beams of groups (5-6) in addition to four beams from groups (1-4) with induced crack depths were examined by UPV device in order to estimate the compressive strengths by UPV device. The results of the compressive strengths of the sixteen samples induced by horizontal cracks gave unrealistic values of compressive strengths so it is very vital and important to estimate the actual compressive strengths of the cracked beams (with induced plastic sheets). Three mixes of SCC were designed as 300, 400 and 500 $\mathrm{kg} / \mathrm{cm}^{2}$ in order to examine different qualities of SCC. Direct method was carried out for each mix for different cross section dimensions 150x200, 150x300 and 150x400 $\mathrm{mm}$. That is mean nine specimens with cross section dimensions $150 \times 300$ of three mixes were prepared for each of three types (control, one crack at $100 \mathrm{~mm}$ depth and two cracks with two depths $100 \mathrm{~mm}$ and $200 \mathrm{~mm}$ ). Another nine beams as the same was prepared but with a natural crack as a construction joint while the age between each separation was 24 hours.

The following parameters were studied according to its tests as follows:

1) Depth of horizontal cracks $(70,100$ and $130 \mathrm{~mm}$ ) for beams with 200 depth and $(100,200$ and $300 \mathrm{~mm})$ for beams with $400 \mathrm{~mm}$ depth.

2) Position of horizontal cracks(edge and middle)

3) Number of horizontal cracks (one and two)

4) Position of ultrasonic pulse velocity transducers (case 1, case 2 and case 3 )

5) Concrete compressive strength $\left(300,400\right.$ and $\left.500 \mathrm{~kg} / \mathrm{cm}^{2}\right)$

\section{MATERIALS}

Normal Portland cement was used (specific gravities: 3.15). The fine aggregate was river sand (specific gravity: 2.61, water absorption: 1.61\%, FM: 2.51). The coarse aggregate had a maximum size of $19 \mathrm{~mm}$. Gravel batches employed were clean, free from impurity matter. The main properties of gravel were measured according to Egyptian standard specifications (ESS 1109-1971). The specific gravity of silica fume and lime stone powder were 2.15 and 2.68 respectively and its chemical proportions was shown in Table (1). F type of high range water reducers (HRWR) superplasticizers based on polycarbocylate was used according to ASTM C494. The type of segregation reducing agent or viscosity enhancement admixture VEA was used by weight of cement.

\section{EXPERIMENTAL PROCEDURE}

The slump tests were carried out according to BS (1881): PART 102: 1983. All destructive tests were carried out on 150x150x150 mm cubes and according to the British Standard BS 1881: Parts, 2 and 116:1983. Non destructive testing were carried out according to BS 1881: Part 205: 1986. Also, all tested specimens were completely dried before both destructive and non destructive testing. The scheme of the experimental work and the number of samples were illustrated in Tables (2 and 3). 
Table (1) Chemical compositions of SF and LSP

\begin{tabular}{|c|c|c|c|c|c|c|c|c|c|c|c|c|c|c|c|}
\hline \multirow[b]{2}{*}{$\begin{array}{l}\text { Powder } \\
\text { type }\end{array}$} & \multicolumn{15}{|c|}{ Percentage of SF and LSP chemical structure } \\
\hline & ర్ & ט & $\frac{\pi}{4}$ & $0^{n}$ & ర్ల & $\stackrel{\text { Oo }}{\sum_{i}}$ & $\tilde{\sigma}^{N}$ & $\begin{array}{l}0 \\
\simeq^{N}\end{array}$ & $\begin{array}{l}0^{N} \\
\varkappa^{2}\end{array}$ & $\theta^{m}$ & $\Xi$ & రెత్త & $\stackrel{2}{=}$ & $\overbrace{\pi}^{m}$ & $\sum_{\sum_{i}^{\infty}}^{m}$ \\
\hline $\begin{array}{l}\text { Silica } \\
\text { fume } \\
\text { SF }\end{array}$ & 96.0 & 0.6 & 0.25 & 0.6 & 0.3 & 0.6 & 0.2 & - & 0.65 & 0.18 & 0.02 & 0.6 & - & - & - \\
\hline $\begin{array}{l}\text { Lime } \\
\text { stone } \\
\text { LSP }\end{array}$ & 7 & - & 2.53 & 1 & 48.8 & 1.15 & 0.5 & - & - & 0.19 & - & 38.9 & - & - & - \\
\hline
\end{tabular}

\section{DISCUSSION OF RESULTS}

Actually, the importance and vital results are shown in figures 1 to 14. the portions for mixes used in this research results are shown in Table (4). Moreover, value of the results for both destructive and non destructive testing after 28 days for SCC are illustrated in Tables (5 and 6). On the other hands, fresh concrete tests were carried out for all mixes used according to ASTM C1611.

\subsection{Detecting Of Horizontal Cracks by UPV (Case 1)}

Figure (1) to Fig.(4) reported the experimental results of the crack depths detected by ultrasonic pulse velocity for SCC beams with induced definite horizontal cracks by inserting a thin plastic sheet at the edge of the beams or at mid-span at different height of the beams depth. This case (Case 1) was set up where the receiver was fixed far from the edge of the beam by $50 \mathrm{~mm}$ and the receiver was movable with $50 \mathrm{~mm}$ intervals up to the end of the beam (far from edge by $50 \mathrm{~mm}$ ). Equation (1) used to investigate the crack depth

$$
\mathrm{Y}=0.5\left(\mathrm{~V}^{2} \mathrm{~T} 2-\mathrm{X}^{2}\right)^{0.5}
$$

Where:

$\mathrm{X}=$ distance between transmitter and receiver

$\mathrm{Y}=$ depth of horizontal crack

$\mathrm{V}=$ velocity of the compression wave through the concrete

$\mathrm{T}=$ transit time

\subsubsection{Case 1: beams with cross section $150 \times 200 \mathrm{~mm}$}

Figures ( 1 and 2 ) represented the relations between the crack depths induced to edge or to the center of the beams (B1-B8) and its corresponding span between transducer and receiver of UPV device.

\section{Induced crack depth to center (Cross sec. 150x200 mm)}

Figure (1) represented the crack depths of the beams B1-B4 with induced crack depth at the center of beams with $150 \times 200 \mathrm{~mm}$ cross section. Crack depth of B1 can be 
detected if the distance between the fixed transducer and receiver between (300-350 $\mathrm{mm}$ ) i.e. approximately at mid span where the position of the crack depth was 70 (66$72 \mathrm{~mm}$ recorded). For B2 which a crack depth of $100 \mathrm{~mm}$ induced recorded a crack depth of ( $91-105 \mathrm{~mm})$ where the distance were $(300-400 \mathrm{~mm})$. B3 with a crack depth of $130 \mathrm{~mm}$ recorded a crack depth of $126 \mathrm{~mm}$ if the distance was $350 \mathrm{~mm}$. Increasing the distance more than $350 \mathrm{~mm}$, unrealistic crack depths were recorded. This may be due to multi-reflections of the pulses from transducer to the receiver due to the long span. On the other hands, B4 with with two cracks was difficult to record the crack depths because the short distance between the 2 cracks $(60 \mathrm{~mm})$ may lead to a multi reflections and hence, crack depth was difficult to be detected.

Table (2) Scheme of the experimental procedure of UPV indirect test

\begin{tabular}{|c|c|c|c|c|}
\hline \multirow{16}{*}{$\begin{array}{l}\text { Total of } 16 \text { SCC } \\
\text { beams with } \\
\text { induced cracks } \\
\text { prepared for } \\
\text { indirect test of } \\
\text { UPV (design } \\
\text { compressive } \\
\text { strength }=400 \\
\left(\mathrm{Kg} / \mathrm{cm}^{2}\right)\end{array}$} & \multirow{8}{*}{$\begin{array}{l}8 \text { Beams have } \\
150 \times 200 \mathrm{~mm} \\
\text { cross section }\end{array}$} & \multirow{2}{*}{$\begin{array}{l}2 \text { beams with induced } \\
\text { crack at } 70 \mathrm{~mm} \text { height }\end{array}$} & Middle crack & B1 \\
\hline & & & Edged crack & B2 \\
\hline & & \multirow{2}{*}{$\begin{array}{l}2 \text { beams with induced } \\
\text { crack at } 100 \mathrm{~mm} \text { height }\end{array}$} & Middle crack & $\mathbf{B 3}$ \\
\hline & & & Edged crack & B4 \\
\hline & & \multirow{2}{*}{$\begin{array}{l}2 \text { beams with induced } \\
\text { crack at } 130 \mathrm{~mm} \text { height }\end{array}$} & Middle crack & B5 \\
\hline & & & Edged crack & B6 \\
\hline & & \multirow{2}{*}{$\begin{array}{l}2 \text { beams with induced } 2 \\
\text { cracks at } 70 \text { and } 130 \\
\text { mm height }\end{array}$} & Middle crack & B7 \\
\hline & & & Edged crack & B8 \\
\hline & \multirow{8}{*}{$\begin{array}{l}8 \text { Beams have } \\
150 \times 400 \mathrm{~mm} \\
\text { cross section }\end{array}$} & \multirow{2}{*}{$\begin{array}{l}2 \text { beams with induced } \\
\text { crack at } 100 \mathrm{~mm} \text { height }\end{array}$} & Middle crack & B9 \\
\hline & & & Edged crack & B10 \\
\hline & & \multirow{2}{*}{$\begin{array}{l}2 \text { beams with induced } \\
\text { crack at } 200 \mathrm{~mm} \text { height }\end{array}$} & Middle crack & B11 \\
\hline & & & Edged crack & B12 \\
\hline & & \multirow{2}{*}{$\begin{array}{l}2 \text { beams with induced } \\
\text { crack at } 300 \mathrm{~mm} \text { height }\end{array}$} & Middle crack & B13 \\
\hline & & & Edged crack & B14 \\
\hline & & \multirow{2}{*}{$\begin{array}{l}2 \text { beams with induced } 2 \\
\text { cracks at } 100 \text { and } 300 \\
\text { mm height }\end{array}$} & Middle crack & B15 \\
\hline & & & Edged crack & B16 \\
\hline 1 beam & $150 \times 200 \mathrm{~mm}$ & \multicolumn{2}{|l|}{ Control } & B17 \\
\hline 1 beam & $150 \times 400 \mathrm{~mm}$ & \multicolumn{2}{|l|}{ Control } & B18 \\
\hline Total $=18$ beams $*$ & & & & \\
\hline
\end{tabular}

*Each beam was tested by UPV indirect method by 3 methods (case 1, case 2 and case 3) 
Table (3) Scheme of the experimental procedure of UPV indirect test

\begin{tabular}{|c|c|c|c|c|c|}
\hline \multirow{2}{*}{$\begin{array}{l}\text { Designed } \\
\text { compressive } \\
\text { strength } \\
\left(\mathrm{Kg} / \mathrm{cm}^{2}\right)\end{array}$} & \multicolumn{2}{|c|}{$\begin{array}{c}\text { Case of induced horizontal } \\
\text { crack }\end{array}$} & \multicolumn{2}{|c|}{$\begin{array}{c}\text { Case of construction } \\
\text { joint }\end{array}$} & \multirow[b]{2}{*}{ contro } \\
\hline & $\begin{array}{l}\text { One crack at } \\
\text { mid-height }\end{array}$ & Two cracks & $\begin{array}{l}\text { One crack } \\
\text { at mid- } \\
\text { height }\end{array}$ & $\begin{array}{l}\text { Two } \\
\text { cracks }\end{array}$ & \\
\hline 300 & B19 & B20 & B21 & B22 & B23 \\
\hline 400 & $\mathrm{~B} 11 *$ & $\mathrm{~B} 15^{*}$ & B24 & $\mathrm{B} 25$ & $\mathrm{~B} 18 *$ \\
\hline 500 & B26 & B27 & B28 & B29 & B30 \\
\hline \multicolumn{6}{|c|}{ *Beams taken from UPV indirect test ( 3 beams) } \\
\hline
\end{tabular}

Table (4) SCC components by weight for one cubic meter

\begin{tabular}{|c|c|c|c|c|c|c|c|c|c|c||}
\hline Mix & $\mathrm{F}_{\text {des }}$ & $\begin{array}{c}\text { OPC } \\
(\text { Kg. })\end{array}$ & $\begin{array}{c}\text { Sand } \\
(\text { Kg. })\end{array}$ & $\begin{array}{l}\text { Gravel } \\
(\text { Kg. })\end{array}$ & $\begin{array}{c}\text { LSP } \\
(\text { Kg. })\end{array}$ & $\begin{array}{c}\text { SF } \\
(\text { Kg. })\end{array}$ & $\begin{array}{c}\text { HRWRA( } \\
\text { Kg. })\end{array}$ & $\begin{array}{c}\text { VEA } \\
(\text { Kg. })\end{array}$ & W/C & $F_{\text {cu }}$ \\
\hline M1 & 300 & 350 & 1108 & 739 & 52.5 & 35 & 7 & 0.35 & 0.33 & 304 \\
\hline M2 & 400 & 400 & 1064 & 709 & 60 & 40 & 8 & 0.40 & 0.3 & 405 \\
\hline M3 & 500 & 500 & 962 & 642 & 75 & 50 & 10 & 0.50 & 0.27 & 506 \\
\hline
\end{tabular}

$\mathrm{F}_{\mathrm{des}}=$ Designed compressive strength

OPC $=$ Ordinary Portland Cement

$\mathrm{C} / \mathrm{F}=$ Coarse to Fine aggregate

LSP=Lime stone powder

$\mathrm{SF}=$ Silica Fume

HRWRA=High Range Water Reducer Admixture

VEA $=$ Viscosity Enhancement Admixture

$\mathrm{W} / \mathrm{C}=$ Water to Cementitious ratio

$\mathrm{F}_{\mathrm{cu}}=$ Fracure compressive strength at 28 days age

Table (5) Results of compressive strengths of horizontal cracked SCC beams.

\begin{tabular}{||c|c|c|c|c||}
\hline \multicolumn{3}{|c|}{ Fracture strength, $\mathrm{F}_{\mathrm{cu}}\left(\mathrm{kg} / \mathrm{cm}^{2}\right)$} & \multicolumn{2}{c||}{$\mathrm{F}_{\mathrm{cu}}$ cracked/ $\mathrm{F}_{\mathrm{cu}}$ control $(\%)$} \\
\hline Control & One crack & Two cracks & One crack & Two cracks \\
\hline 304 & 287 & 254 & 94.4 & 83.6 \\
\hline 404.7 & 353 & 316 & 87.2 & 78.1 \\
\hline 506 & 448 & 439 & 88.5 & 86.8 \\
\hline \multicolumn{2}{|c|}{ Average $\left(\mathrm{F}_{\mathrm{cu}}\right.$ cracked $) /\left(\mathrm{F}_{\mathrm{cu}}\right.$ control $)(\%)$} & 90.0 & 82.8 \\
\hline
\end{tabular}


Table (6) Results of compressive strengths of SCC beams with construction joints

\begin{tabular}{|c|c|c|c|c|}
\hline \multicolumn{3}{|c|}{ Fracture strength, $\mathrm{F}_{\mathrm{cu}}\left(\mathrm{kg} / \mathrm{cm}^{2}\right)$} & \multicolumn{2}{c|}{$\mathrm{F}_{\mathrm{cu}}$ cracked/ $\mathrm{F}_{\mathrm{cu}}$ control $(\%)$} \\
\hline Control & One crack & Two cracks & One crack & Two cracks \\
\hline 304 & 285 & 260 & 93.8 & 85.5 \\
\hline 404.7 & 360.7 & 339 & 89.1 & 83.8 \\
\hline 506 & 457.3 & 448.7 & 90.4 & 88.7 \\
\hline \multicolumn{2}{|c|}{ Average $\left(\mathrm{F}_{\mathrm{cu}}\right.$ cracked $) /\left(\mathrm{F}_{\mathrm{cu}}\right.$ control $)(\%)$} & 91.1 & 86 \\
\hline
\end{tabular}

\section{Distance between transmitter and reciever $(\mathrm{X})$}

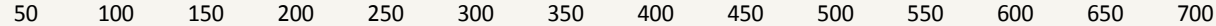

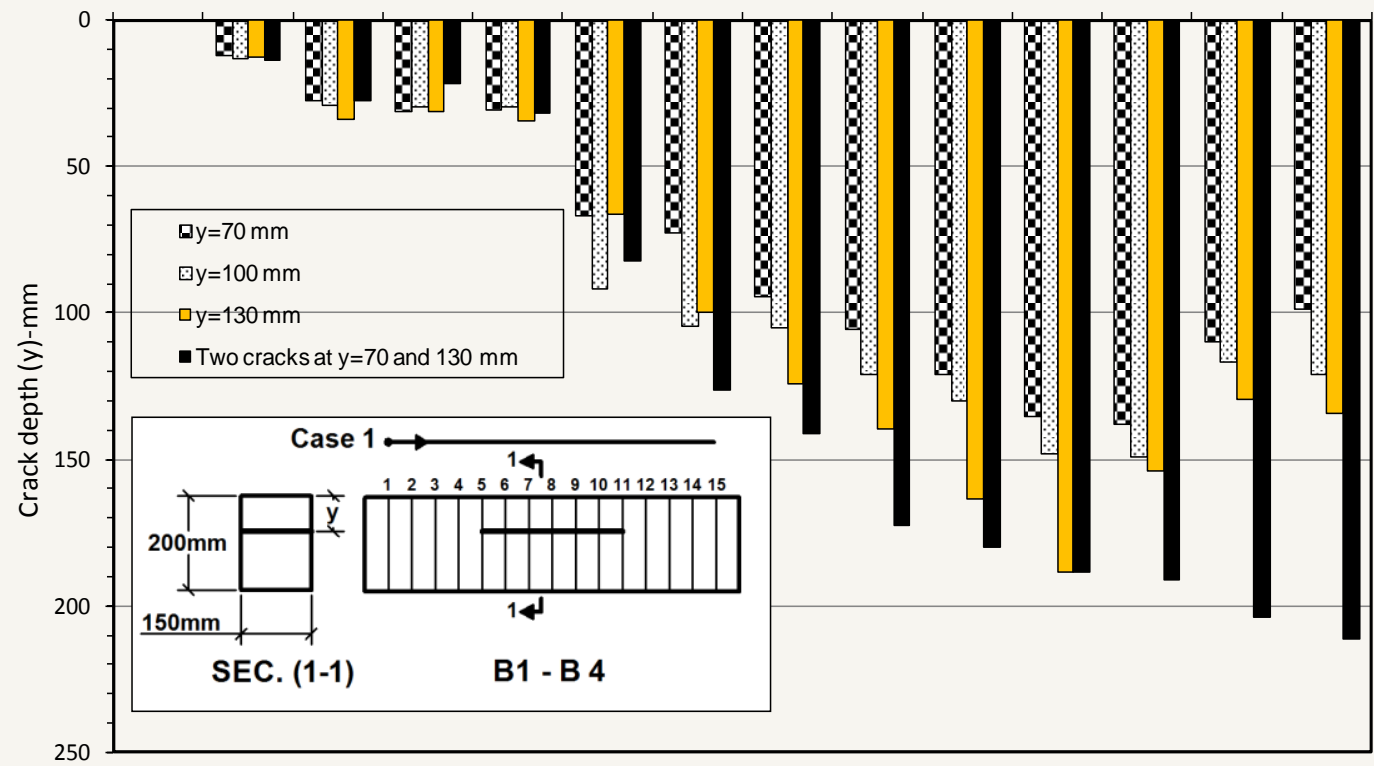

Fig. (1) Crack depth of Case 1-induced crack to center (C.S. 150x200 mm)

\section{Induced crack depth to edge (Cross sec. 150x200 mm)}

Figure (2) showed the crack depths of the beams B5-B8 with a $200 \mathrm{~mm}$ depth but the cracks were induced at the edge of the beams. Crack depth of B5, with induced crack depth $70 \mathrm{~mm}$, may be detected if the distance was $(150-200 \mathrm{~mm})$ where the recorded cracks were in between $(65-69 \mathrm{~mm})$. B6 with induced crack depth of $100 \mathrm{~mm}$ also gave a crack depth of (91-92 mm) if the distances were in between $(150-200 \mathrm{~mm})$. B7 with an induced crack depth of $130 \mathrm{~mm}$ can be detected as a crack depth of $108 \mathrm{~mm}$ for a distance of $100 \mathrm{~mm}$. Figure showed also that UPV cannot detect the crack depths of beams have two cracks (B8) where it can detect only the top crack $(69 \mathrm{~mm})$ when the distance was $150 \mathrm{~mm}$. If the distance between the transducer and receiver were more than (100-200 mm), unrealistic crack depths were detected as shown in Fig. (2). This may due to the multi reflection of the pulsed due to the long span. 


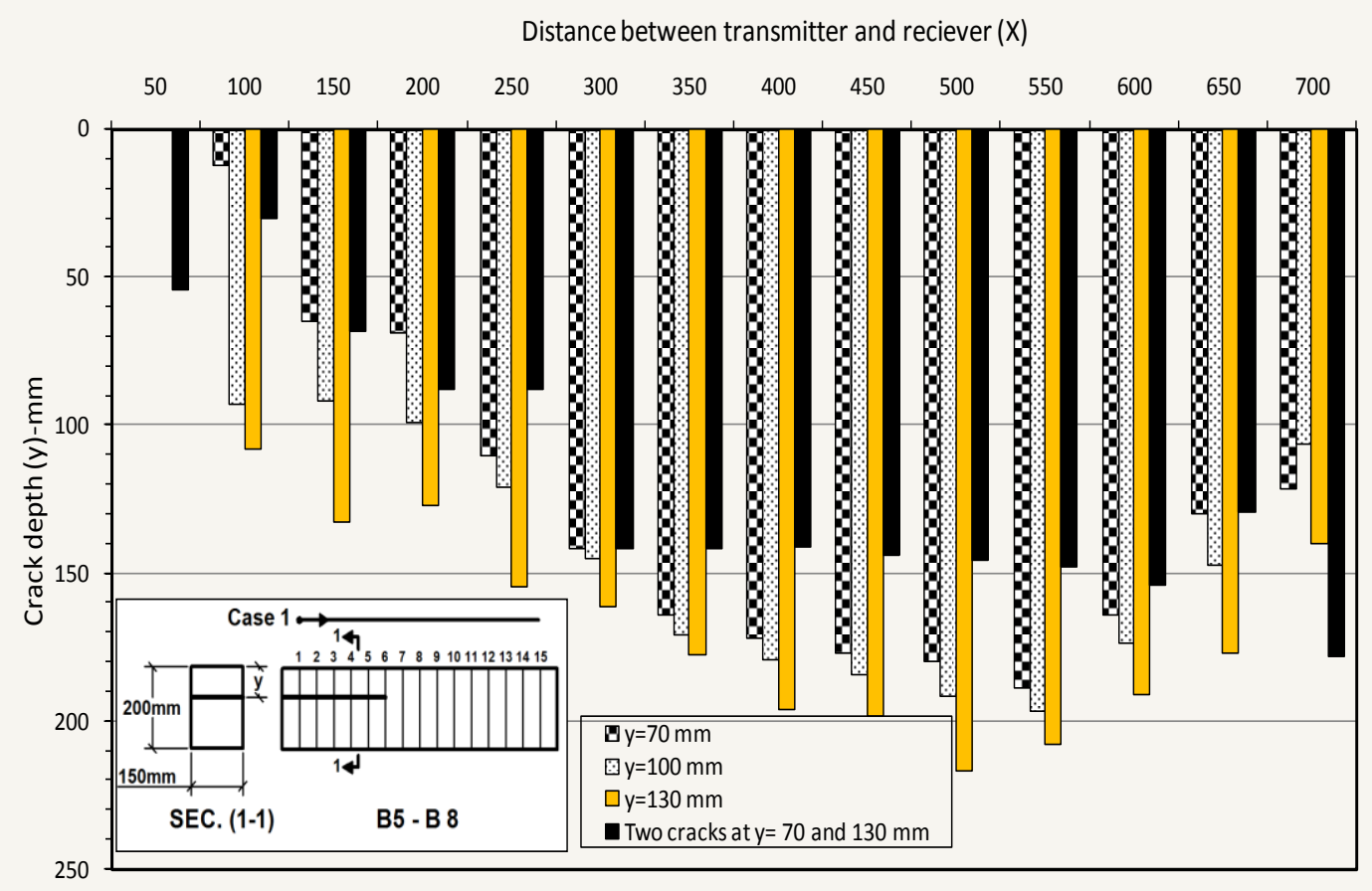

Fig. (2) Crack depth of Case 1-induced crack to edge (C.S. 150x200 mm)

\subsubsection{Case 1: beams with cross section $150 \times 400 \mathrm{~mm}$}

Figures ( 3 and 4) illustrated the crack depths of the beams B9-B16 with a cross section of $150 \times 400 \mathrm{~mm}$ and cracks were induced to the center or to the edge of the beams with different induced crack depths 100, 200 and $300 \mathrm{~mm}$ as one crack in addition to two cracks with a depths of $100 \mathrm{~mm}$ and $300 \mathrm{~mm}$ from top to surface of beams.

\section{Induced crack depth to center (Cross sec. $150 \times 400 \mathrm{~mm}$ )}

Figure (3) exhibited the detected crack depths for B9 with a crack depth of $100 \mathrm{~mm}$. results showed that the crack depth may be detected if the distances between the transducer and receiver were in between $(400-500 \mathrm{~mm})$ with a detected crack depths between $(94-110 \mathrm{~mm})$. B10 with an induced crack depth of $200 \mathrm{~mm}$ can be detected only if the distances were $(450-550 \mathrm{~mm})$ which gave crack depths of $(195-200 \mathrm{~mm})$. B11 with induced crack depth of $300 \mathrm{~mm}$ can be also detected as $(296-306 \mathrm{~mm})$ if the distances were (450-500). B12 with induced two cracks can be detected only by the top crack depth which receive the pulse before the deeper crack hence top crack only may be detected if the distances were $(400-450 \mathrm{~mm})$ which detected the crack depth of $(100$ $104 \mathrm{~mm})$. 
Distance between transmitter and reciever (X)

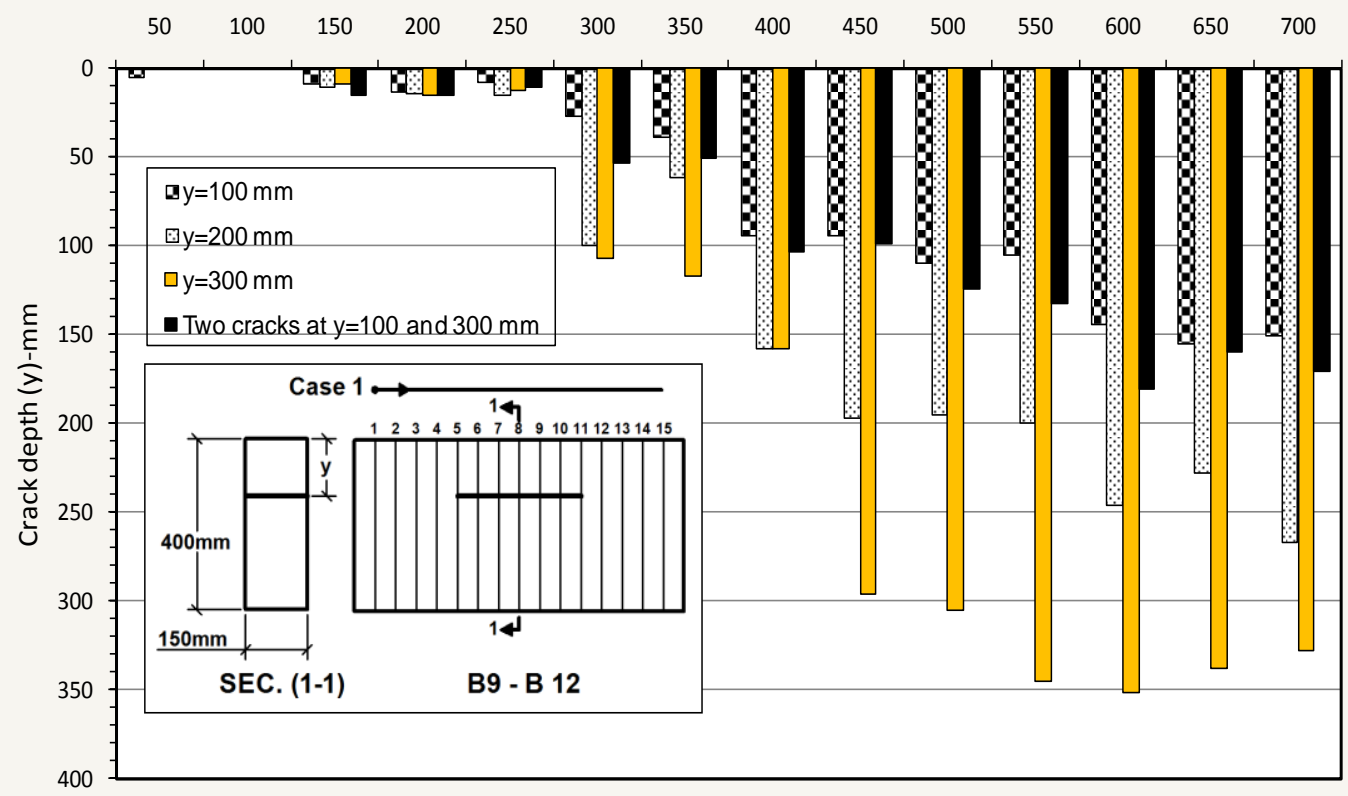

Fig. (3) Crack depth of Case 1-induced crack to center (C.S. 150x400 mm)

Distance between transmitter and reciever $(X)$

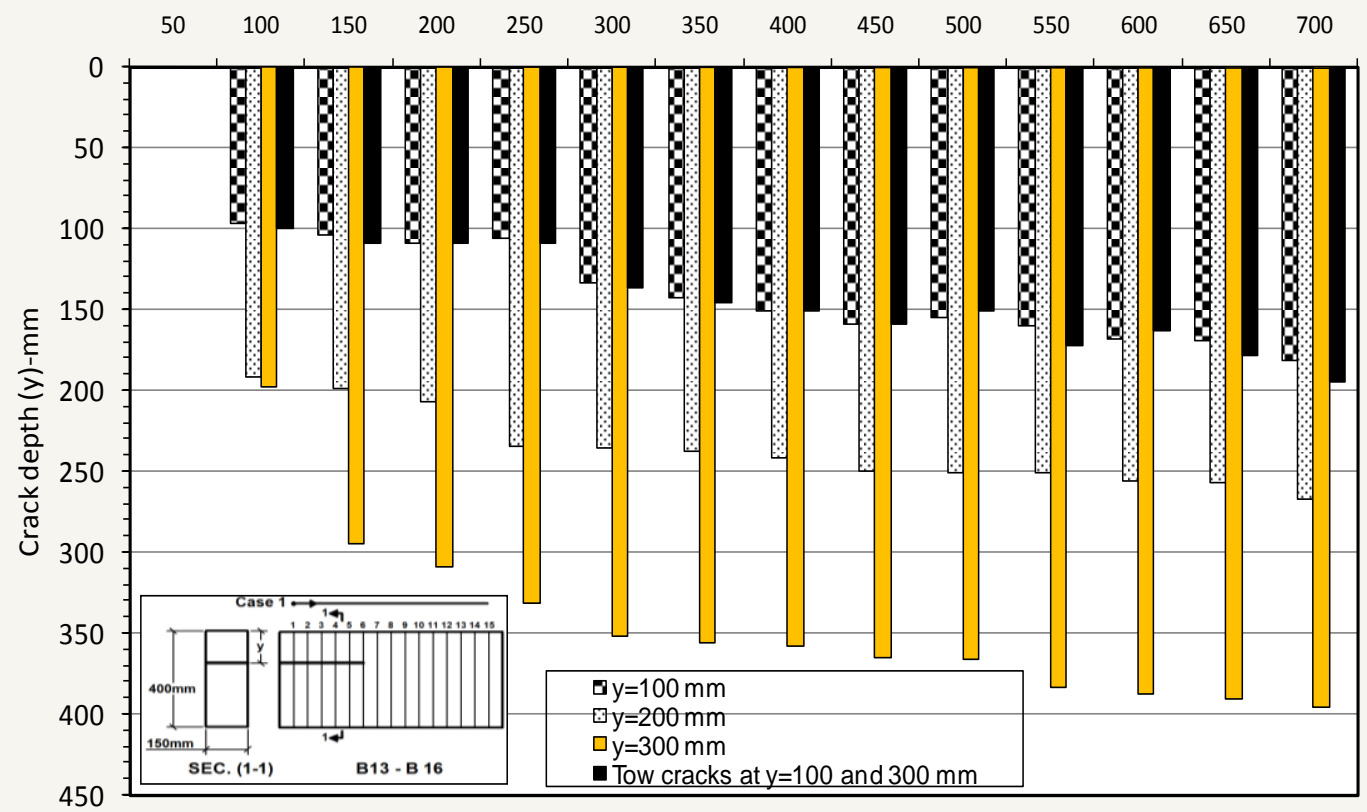

Fig. (4) Crack depth of Case 1-induced crack to edge (C.S. 150x200 mm)

\section{Induced crack depth to edge (Cross sec. 150x400 mm)}

Figure (4) reported the results of the crack depths induced to the edge of the beams (B13-B16). Figure indicated that B13 with an induced crack depth of $100 \mathrm{~mm}$ can be 
detected if the distance were $(100-250 \mathrm{~mm})$ where the detected cracks were (97-109 $\mathrm{mm})$. B14 with induced crack depth of $200 \mathrm{~mm}$ indicated crack depths of (198-207 $\mathrm{mm}$ ) if the distanced were (100-200 mm). Induced crack depth of $300 \mathrm{~mm}$ in B15 can be detected if the distances were (150-200 mm) which indicated a crack depth of (295$309 \mathrm{~mm}$ ). on the other hands, B16 with an induced 2 crack depths cannot be detected because the top crack only receive the pulses and hence the cracks detected were (100$109 \mathrm{~mm}$ ) if the range of the distance were (100-250) as B13 with one top induced crack depth.

\subsection{Detecting Of Horizontal Cracks by UPV (Case 2)}

Figures ( 5 to 8 ) exhibited the experimental results of the crack depths detected by ultrasonic pulse velocity for SCC beams with induced definite horizontal cracks by inserting a thin plastic sheet in the edge of the beams or at mid-span at different height of the beams depth. Case 2 of UPV device was setup as the transducer and receiver were centered at a distance of $100 \mathrm{~mm}$ (each pole far from $50 \mathrm{~mm}$ from the center) and moved together towards the edge at intervals $100 \mathrm{~mm}$ up to a distance of $700 \mathrm{~mm}$.

\subsubsection{Case 2: beams with cross section $150 \times 200 \mathrm{~mm}$}

Figures (5 and 6) represented the results of the detected crack depths with the distance between the transducer and the receiver for the beams B1-B8 with the cross section 150x200 mm.

\section{Induced crack depth to center (Cross sec. 150x200 mm)}

Figure (5) illustrated the crack depths of beams with induced cracks in the center of the beams. B1 with $70 \mathrm{~mm}$ induced crack depth can be detected if the distances were (100$200 \mathrm{~mm}$ ) with a detected crack depth of $(69-75 \mathrm{~mm})$. B2 with induced crack depth of $100 \mathrm{~mm}$ can also be indicated if the distances were $(100-200 \mathrm{~mm})$ with a detected crack depth of $92 \mathrm{~mm}$. B3 with induced crack depth of $130 \mathrm{~mm}$ was detected if the distances were (100-200 mm) with a detected crack depth of $124 \mathrm{~mm}$. on the other hands, B4 with 2 cracks layers cannot be detected because of the small cross section with a short distances between the two cracks $(6 \mathrm{~mm})$.

\section{Induced crack depth to edge (Cross sec. 150x200 mm)}

Figure (6) illustrated the detected crack depth by UPV of beams with induced crack at edge of beams which can be detected where B5 with induced crack depth of $70 \mathrm{~mm}$ can be detected if the distance were $100 \mathrm{~mm}$ which gave a detected crack depth of 73 $\mathrm{mm}$. B6 with induced crack depth of $100 \mathrm{~mm}$ represented a detected crack depth of (94-99) if the distances were (100-200 mm). B7 with $130 \mathrm{~mm}$ induced crack depth can be detected if the distances were $(100-200 \mathrm{~mm})$ with a detected crack depth of (129$133 \mathrm{~mm}$ ). On the other hand, crack depths cannot be detected if the beams B8 contains two cracks that is may be due to the small cross section with a small depth between the two cracks $(6 \mathrm{~mm})$. 


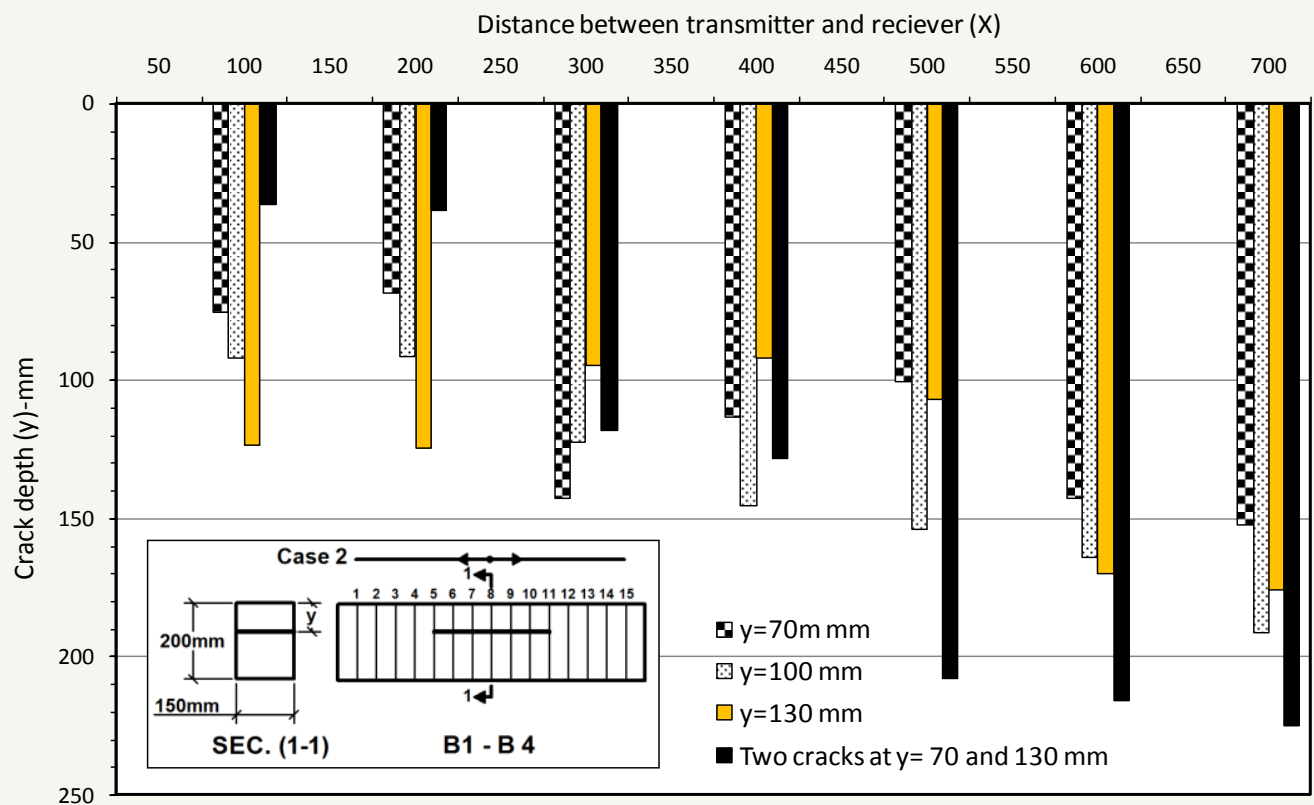

Fig. (5) Crack depth of Case 2-induced crack to center (C.S. 150x200 mm)

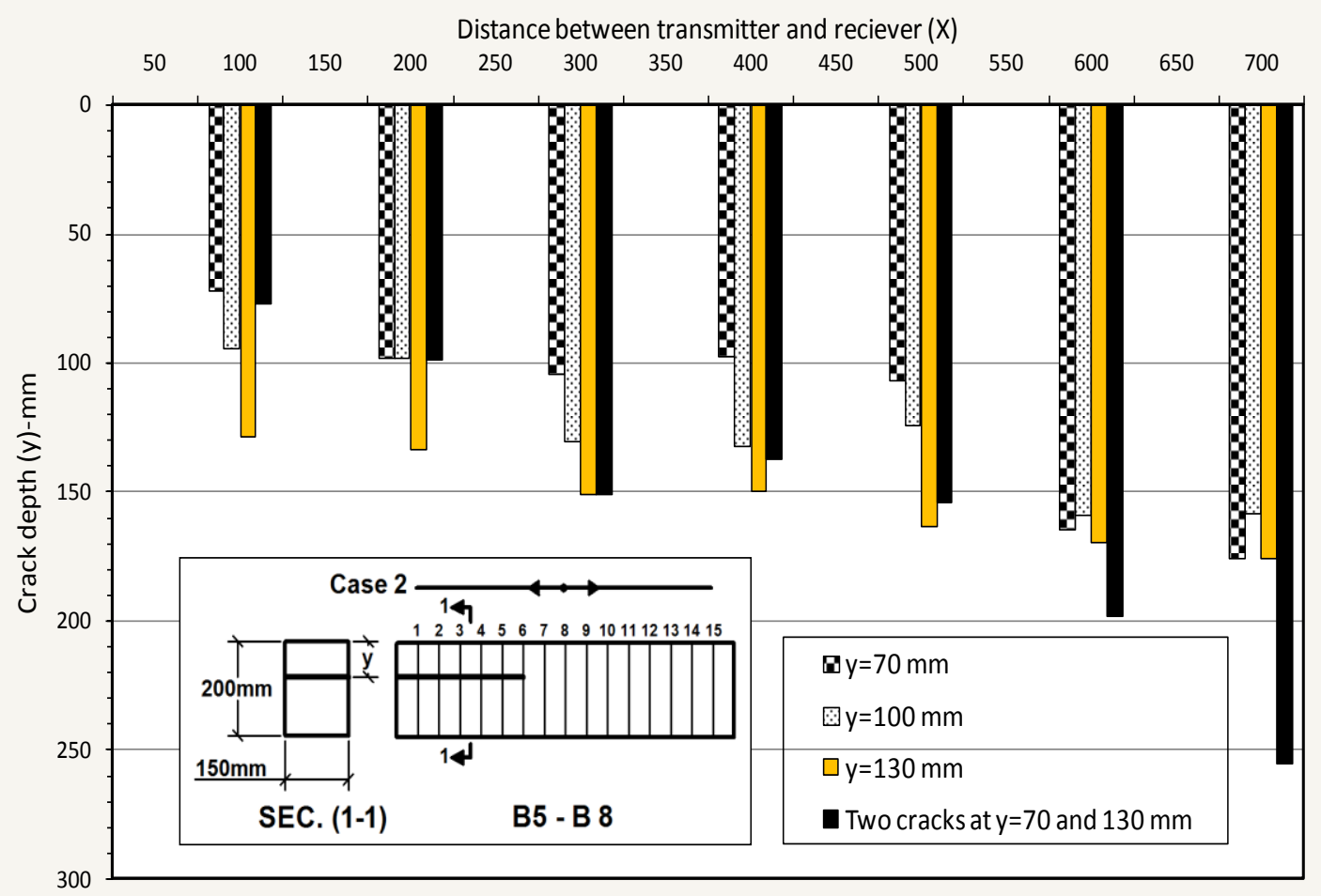

Fig. (6) Crack depth of Case 2-induced crack to edge (C.S. 150x200 mm) 


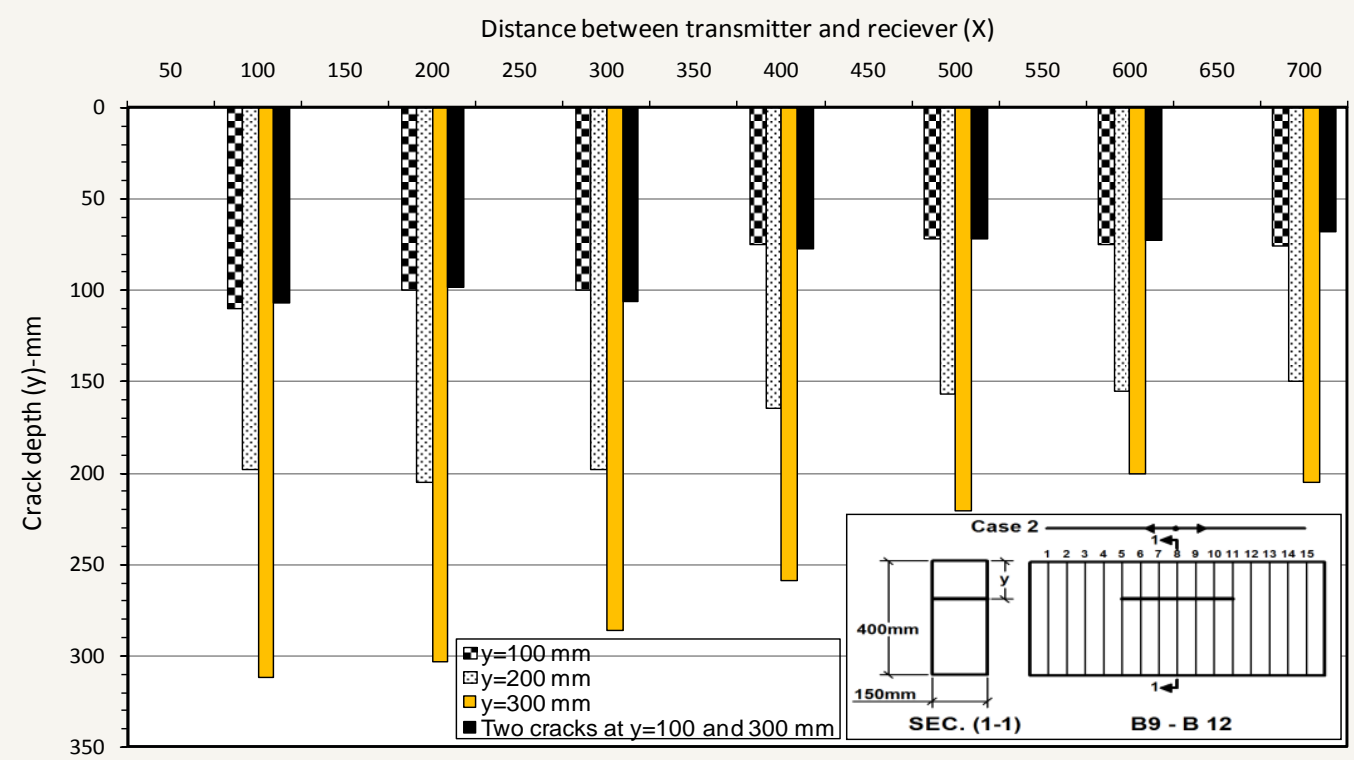

Fig. (7) Crack depth of Case 2-induced crack to center (C.S. 150x400 mm)

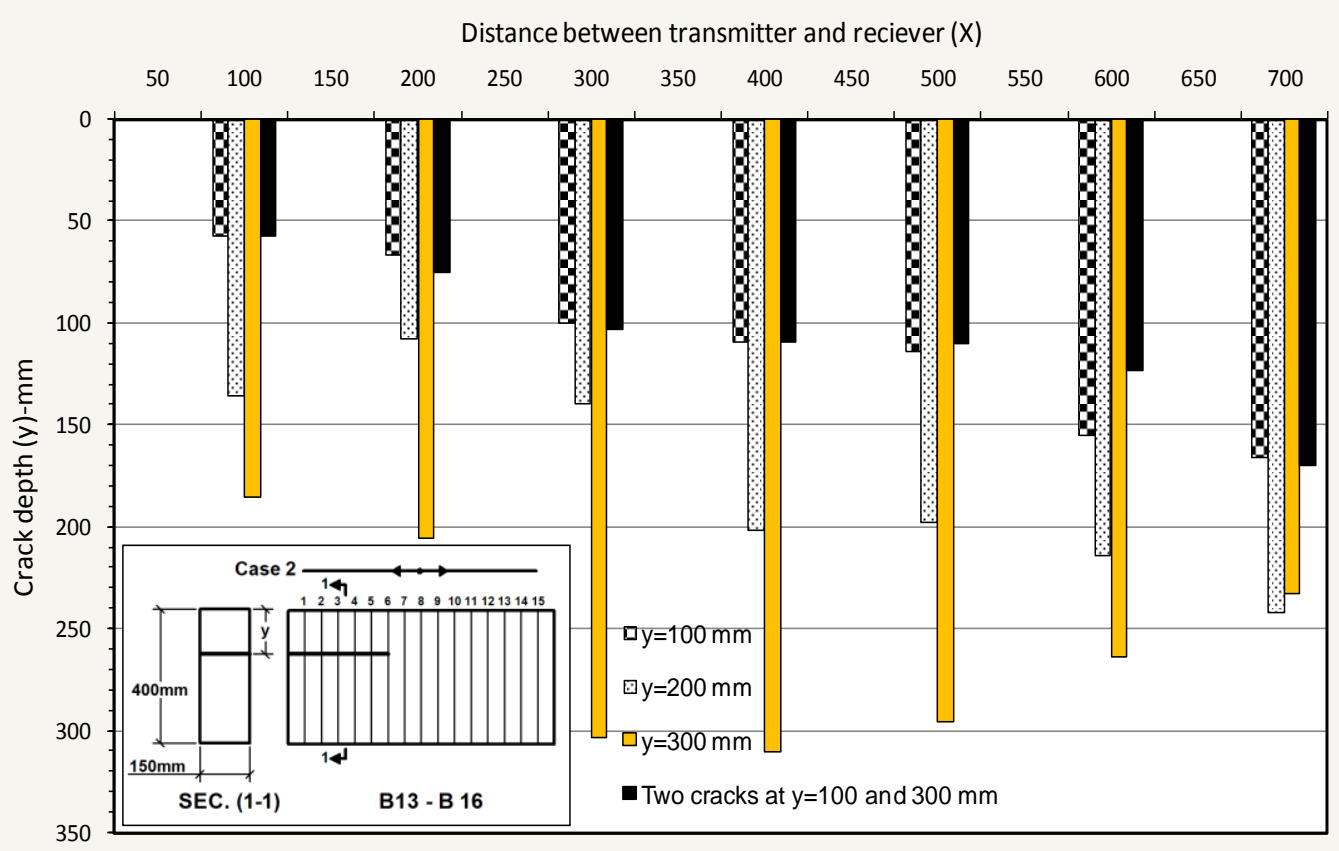

Fig. (8) Crack depth of Case 1-induced crack to edge (C.S. 150x400 mm)

\subsubsection{Case 2: beams with cross section $150 \times 400 \mathrm{~mm}$}

Figures (7 and 8) illustrated the detected crack depths of beams B9-B16 with induced crack depths in the center of the beams with cross section depth of $400 \mathrm{~mm}$. 


\section{Induced crack depth to center (Cross sec. $150 \times 400 \mathrm{~mm}$ )}

Figure (7) showed the crack depths of B9-B12 with induced crack depths at center of beams which can be detected. B9 illustrated a crack depth of $(100-110 \mathrm{~mm})$ if the distances were $(100-300 \mathrm{~mm})$. B10 with $200 \mathrm{~mm}$ induced crack depth was detected if the distances were $(100-300 \mathrm{~mm})$ with a crack depth of $(198-205 \mathrm{~mm})$. B11 with 300 $\mathrm{mm}$ induced crack depth also can be detected if the distances were $(100-300 \mathrm{~mm})$ with (286-311 mm) induced crack depths. The two induced cracks of B12 detected the top crack only $(98-106 \mathrm{~mm})$ through distances of $(100-300 \mathrm{~mm})$. This may due to the reasonable distance between the 2 cracks which enable the top crack to receive the pulses before the down crack.

\section{Induced crack depth to edge (Cross sec. $150 \times 400 \mathrm{~mm}$ )}

Figure (8) illustrated the detected crack depths of beams B13-B16 with induced crack depths at center of beams. B13 can be detected if the distance between transducer and receiver in between $(300-500 \mathrm{~mm})$ which gave a detected crack depths of (100-113 $\mathrm{mm})$. B14 also can be detected if the distances were $(300-500 \mathrm{~mm})$ with detected crack depths of (197-202 mm). B15 can be detected the distances were $(400-500 \mathrm{~mm})$ which indicated a crack depths of $(295-310 \mathrm{~mm})$. Elsewhere, 2 layer cracks induced in B16 detected the top crack when the distances were $(300-500 \mathrm{~mm})$ which indicated a crack depth of (103-110 mm).

\subsection{Detecting Of Horizontal Cracks By UPV (Case 3)}

Figures (9 to 12) reported the experimental results of the detected crack depths by UPV device which measure the beams from its center point to its edges where the transducer was fixed to the center of beams and the receiver was movable towards the edge with $50 \mathrm{~mm}$ intervals covering the area induced by horizontal cracks.

\subsubsection{Case 3: Beams with cross section 150x200 mm}

Figures (9 and 10) showed the crack depths of the beams with 150x200 mm cross section with the distances between transducer and receiver. Plastic sheets were induced to those eight beams from B1-B8 either in the middle of beams as B1-B4 or induced to edge as B5-B8.

\section{Induced crack depth to center (Cross sec. 150x200 mm)}

Figure (9) indicated the crack depths of beams B1-B4 which represented the detected crack depth for all beams with different crack depths. B1 with $70 \mathrm{~mm}$ induced crack depth was detected if the distances between transducer and receiver were (100-150 $\mathrm{mm})$ which gave a detected crack depth of $(66-74 \mathrm{~mm})$. B2 with 100 induced crack depths also can be detected when the distances were $(100-200 \mathrm{~mm})$ with $(96-98 \mathrm{~mm})$ crack depths. The detected depths for B3 with $130 \mathrm{~mm}$ induced crack depth were detected by the same distances between transducer and receiver of B1 and B2 (100-150 $\mathrm{mm}$ ) which represent a crack depth of (131-133 mm). Elsewhere, B4 with induced 2 crack depths at $70 \mathrm{~mm}$ and $130 \mathrm{~mm}$ from top of the cross section cannot be investigated because of small dimensions of the cross section with a short distance between the two cracks $(60 \mathrm{~mm})$ which may cause multi-reflections hence, unrealistic crack depths are shown in the figure. 
Distance between transmitter and reciever $(\mathrm{X})$

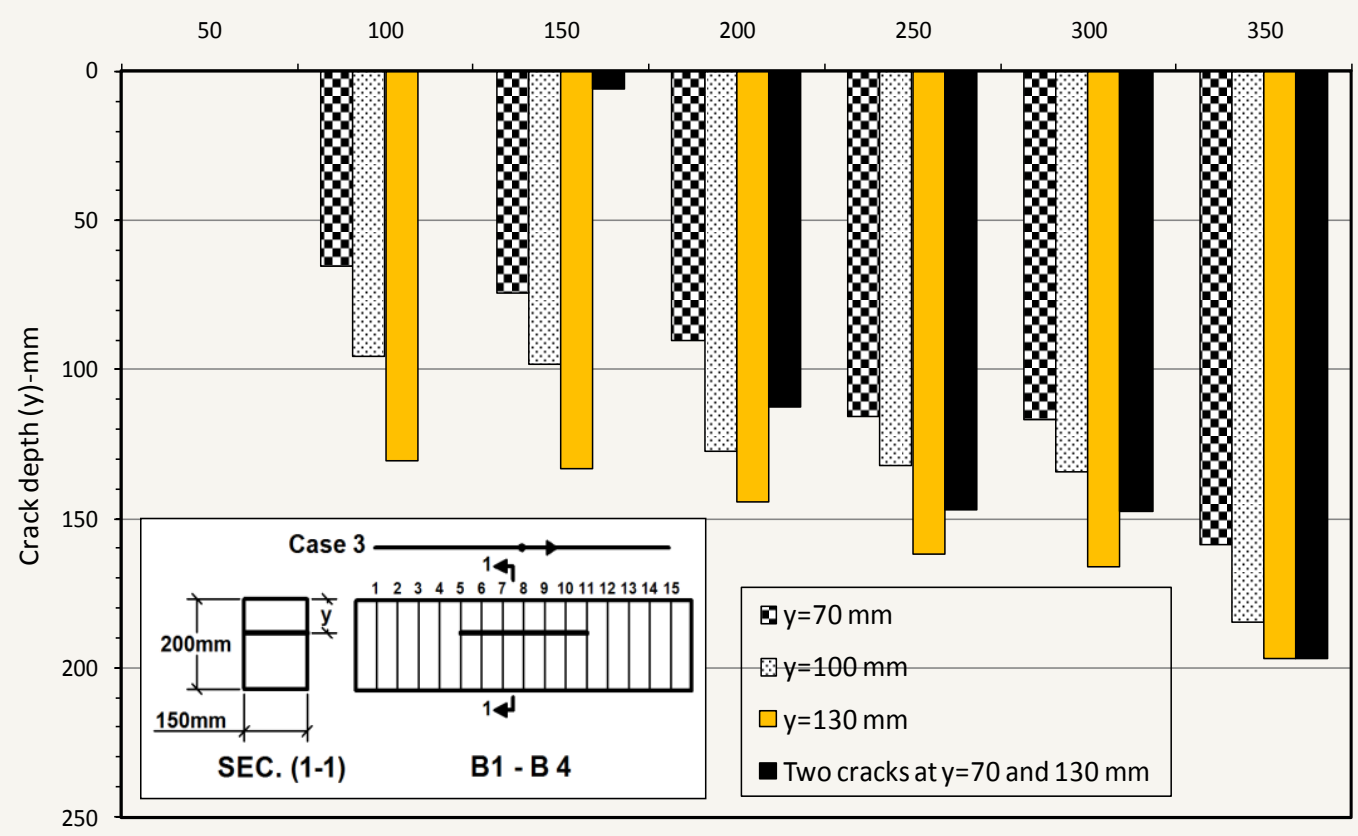

Fig. (9) Crack depth of Case 3-induced crack to center (C.S. 150x200 mm)

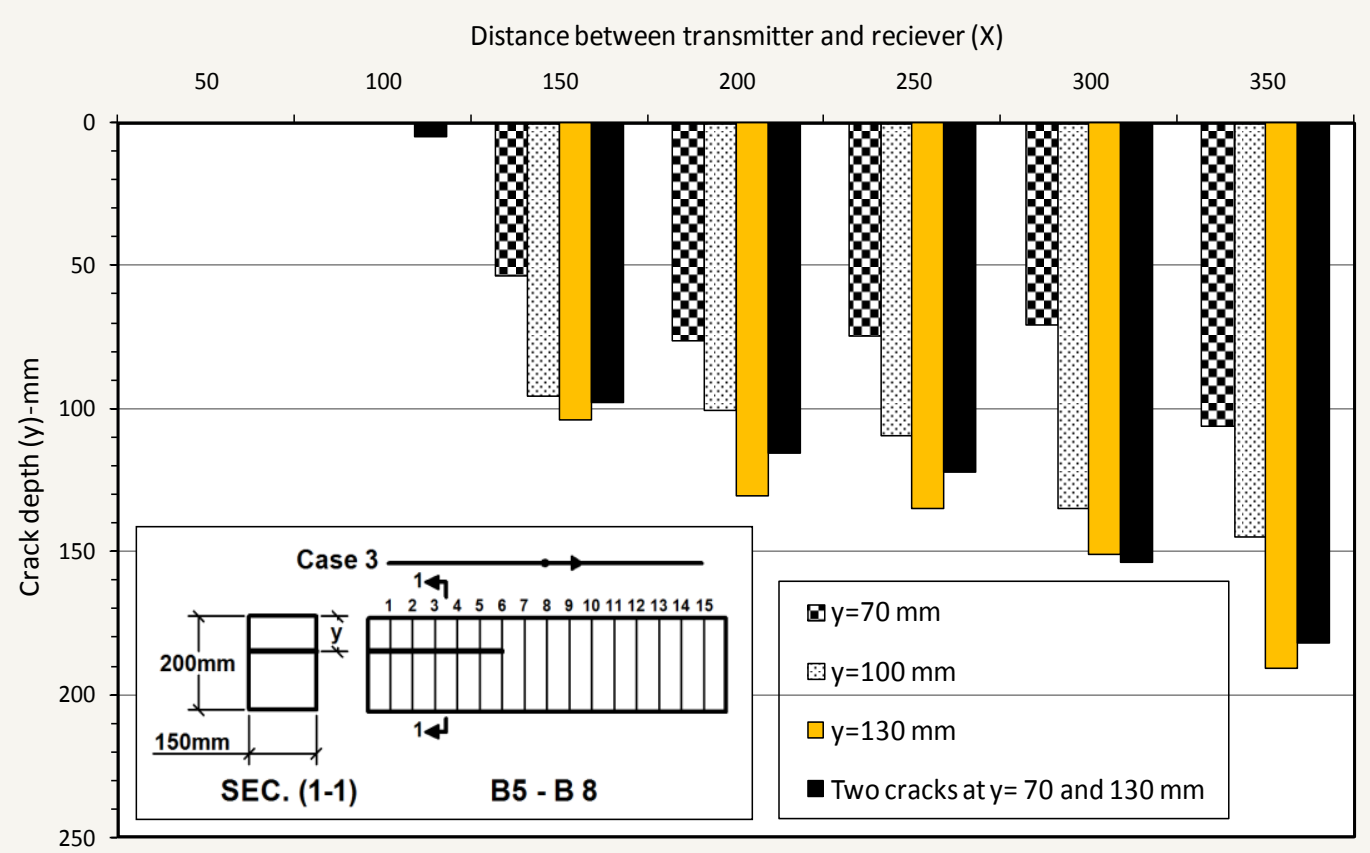

Fig. (10) Crack depth of Case 3-induced crack to edge (C.S. 150x200 mm) 


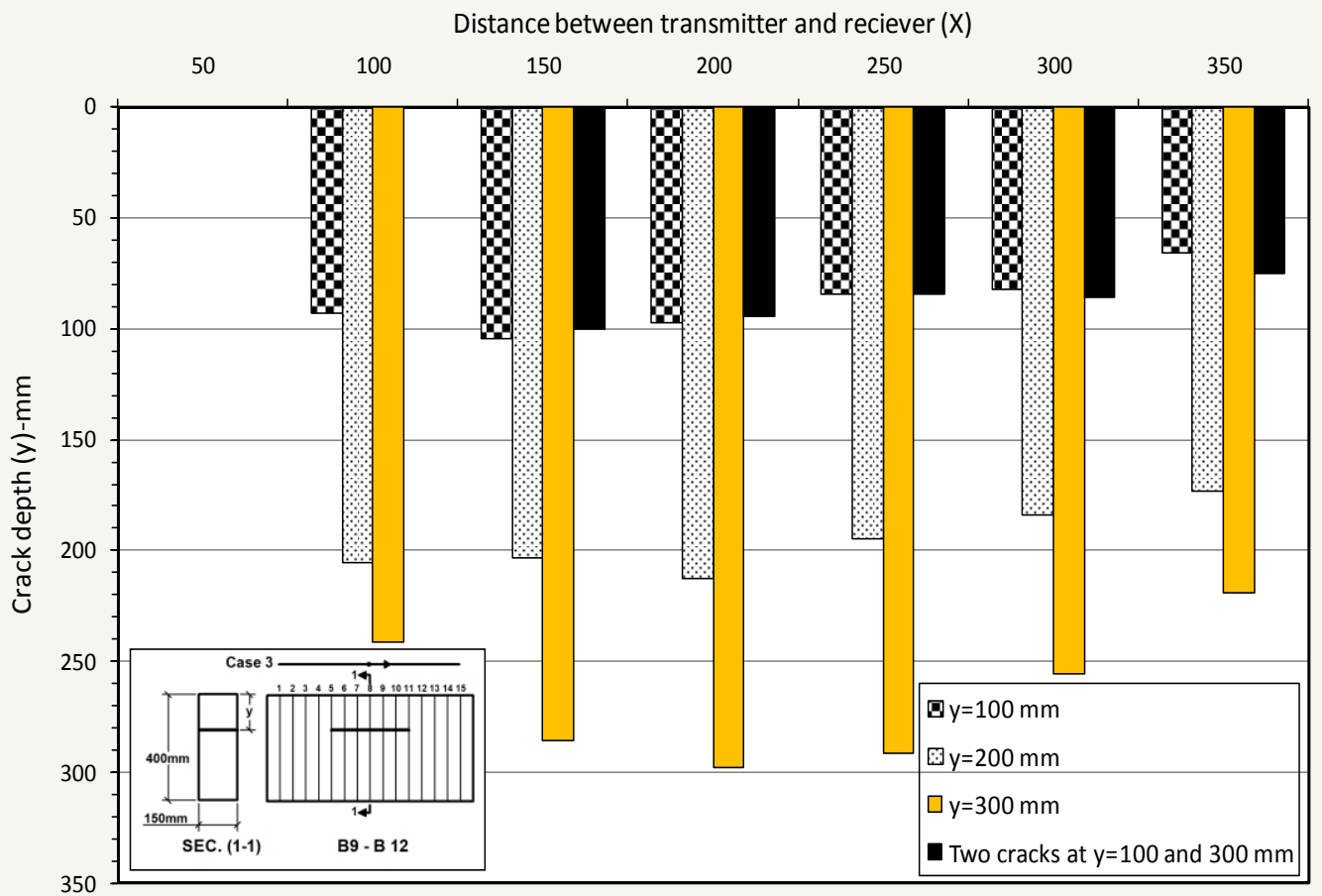

Fig. (11) Crack depth of Case 3-induced crack to center (C.S. 150x400 mm)

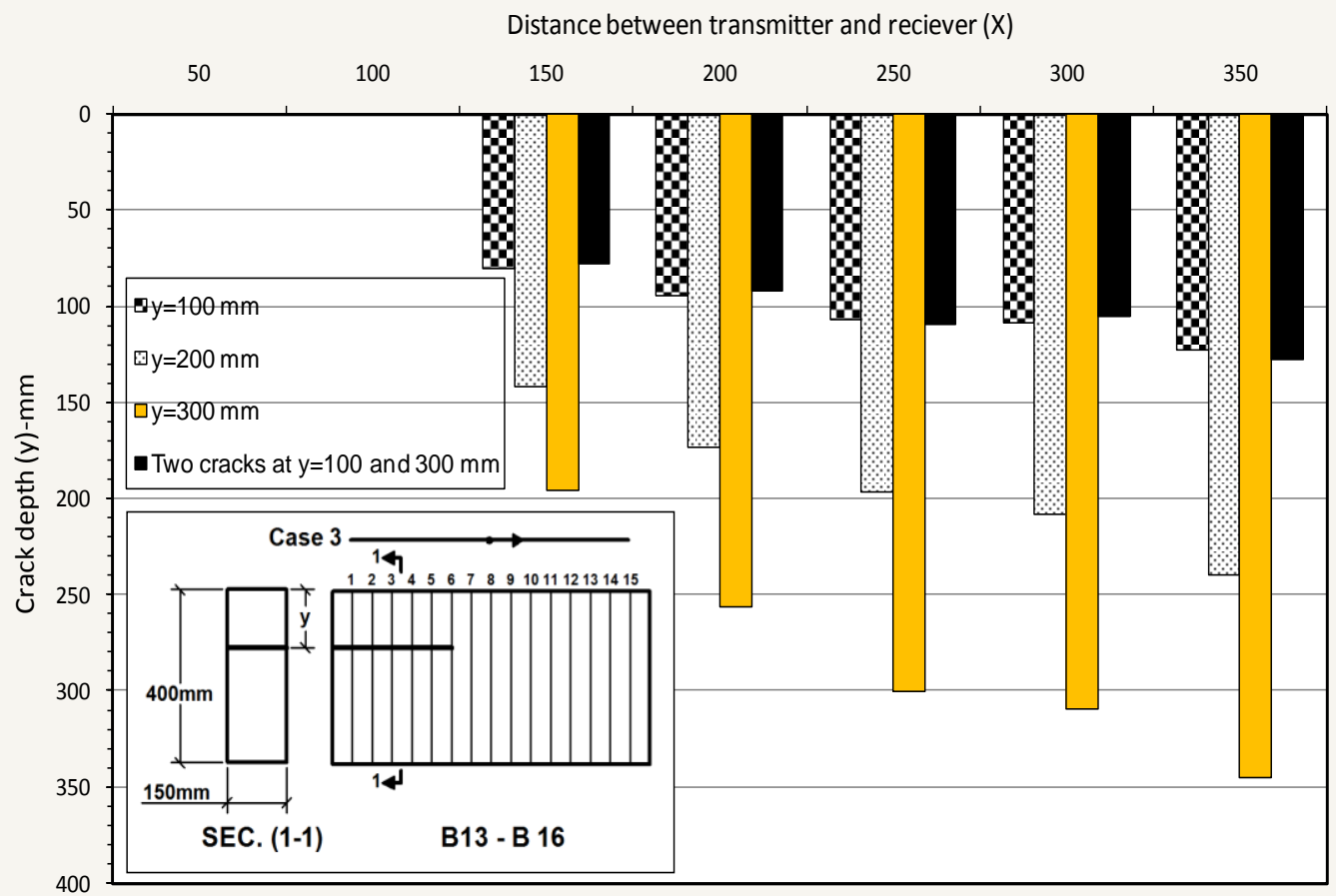

Fig. (12) Crack depth of Case 3-induced crack to edge (C.S. 150x400 mm) 


\section{Induced crack depth to edge (Cross sec. $150 \times 200 \mathrm{~mm}$ )}

Figure (10) represented the crack depths by UPV device for the beams B5 to B8 and which have induced crack depths to the edge beams. B5 with $70 \mathrm{~mm}$ induced crack depths indicated $\quad(70-75 \mathrm{~mm})$ crack depth when the distances were $(150-250 \mathrm{~mm})$ whereas B6 with $100 \mathrm{~mm}$ induced crack depth represented $(95-109 \mathrm{~mm})$ crack depths when the distances were (200-300 mm). B7 indicated also the crack depths of (130-135 $\mathrm{mm}$ ) when the distances were in the range $(200-250 \mathrm{~mm})$. On the hand, crack depths of the B8 with two induced cracks gave unrealistic values that are because of the multireflections of the pulses and small dimensions of the cross section.

\subsubsection{Case 3: beams with cross section $150 \times 400 \mathrm{~mm}$}

Figure (11 to 12) reported the results of the beams with $150 \times 400 \mathrm{~mm}$ of the eight beams (B9 to B16) which measured as indicated in case 3 where cracks induced either center or edge of the beams.

\section{Induced crack depth to center (Cross sec. $150 \times 400 \mathrm{~mm}$ )}

Figure (11) showed the crack depths of the four beams which have a crack depths induced to center of beams B9 to B12. Results exhibited that B9 of $100 \mathrm{~mm}$ induced crack depth may be detected through a distances of $(100-200 \mathrm{~mm})$ with a crack depths of (93-104 mm). B10 with 200 induced crack depths was investigated and the crack can be detected when the distances were $(100-250 \mathrm{~mm})$ which gave $(194-212 \mathrm{~mm})$ crack depths. B11 with $300 \mathrm{~mm}$ induced crack depth represented a detected crack depth of $(285-298 \mathrm{~mm})$ through the distances $(150-250 \mathrm{~mm})$. B12 with two cracks in levels $100 \mathrm{~mm}$ and $300 \mathrm{~mm}$ can be detected for its top crack only when the distances were $(150-200 \mathrm{~mm})$ where as the crack depths were $(94-100 \mathrm{~mm})$. The reasonable distances between the two cracks $(200 \mathrm{~mm})$ enabled the top crack to receive the pulses and reflect it to the receiver without any multi-reflections.

\section{Induced crack depth to edge (Cross sec. $150 \times 400 \mathrm{~mm}$ )}

Figure (12) explained the relations between the crack depths of beams (B13 to B16) and the distances of the transmitter and receiver of the induced crack depths to the edge of beams. B13 with $100 \mathrm{~mm}$ induced crack depths may be investigated when the distances were (200-300 mm) which gave a crack depth of (94-108 mm). B14 with 200 $\mathrm{mm}$ induced crack depth indicated a detected crack depth of $(196-208 \mathrm{~mm})$ when the distances were $(250-300 \mathrm{~mm})$. It is clearly shown that B15 with $300 \mathrm{~mm}$ induced crack depth can be investigated through distances $\mathrm{f}(250-300 \mathrm{~mm})$ where the detected cracks were $(300-309 \mathrm{~mm})$. On the hand, B16 with two cracks detected only the top crack with $100 \mathrm{~mm}$ depths at distances $(200-300 \mathrm{~mm})$ where the cracks were $(92-109 \mathrm{~mm})$.

\subsection{Compressive strengths of SCC Have horizontal cracks by UPV}

The vital and important calibration curves of the cracked SCC should prepared by direct method in order to estimate the compressive strengths of the cracked SCC that is because indirect method failed to detect the compressive strengths and gave unrealistic values. Results of group 5 showed that control sample of SCC can be investigated by 
UPV by a calibration curve between UPV and fracture compressive strengths as indicated in Equation (2).

$$
\mathrm{F}_{\mathrm{cu}}=1361.1 \mathrm{Ln}(\mathrm{V})-1670.4
$$

Where:

$\mathrm{F}_{\mathrm{cu}}=$ Actual compressive strength of the control sample

$\mathrm{V}=$ Ultrasonic pulse velocity

Figure (13) also indicated the results of the compressive strengths of the group 5 with induced one crack depth which can represent also by Equation (3):

$$
\mathrm{F}_{\mathrm{cu}}=480.51 \mathrm{Ln}(\mathrm{V})-43.118
$$

Results of investigation group 5 with induced two cracks depths illustrated in Fig. (13) and Equation (4):

$$
\mathrm{Fcu}=788.37 \mathrm{Ln}(\mathrm{V})-145.84
$$

It is shown from Fig. (13) that compressive strengths of the cracked SCC can be estimated by UPV device but with direct method.

Table (5) represented the fracture compressive strengths of SCC with induced cracks with related to the control SCC. Table showed that fracture strength of SCC with one crack was $90 \%$ whereas SCC with two cracks was about $83 \%$.

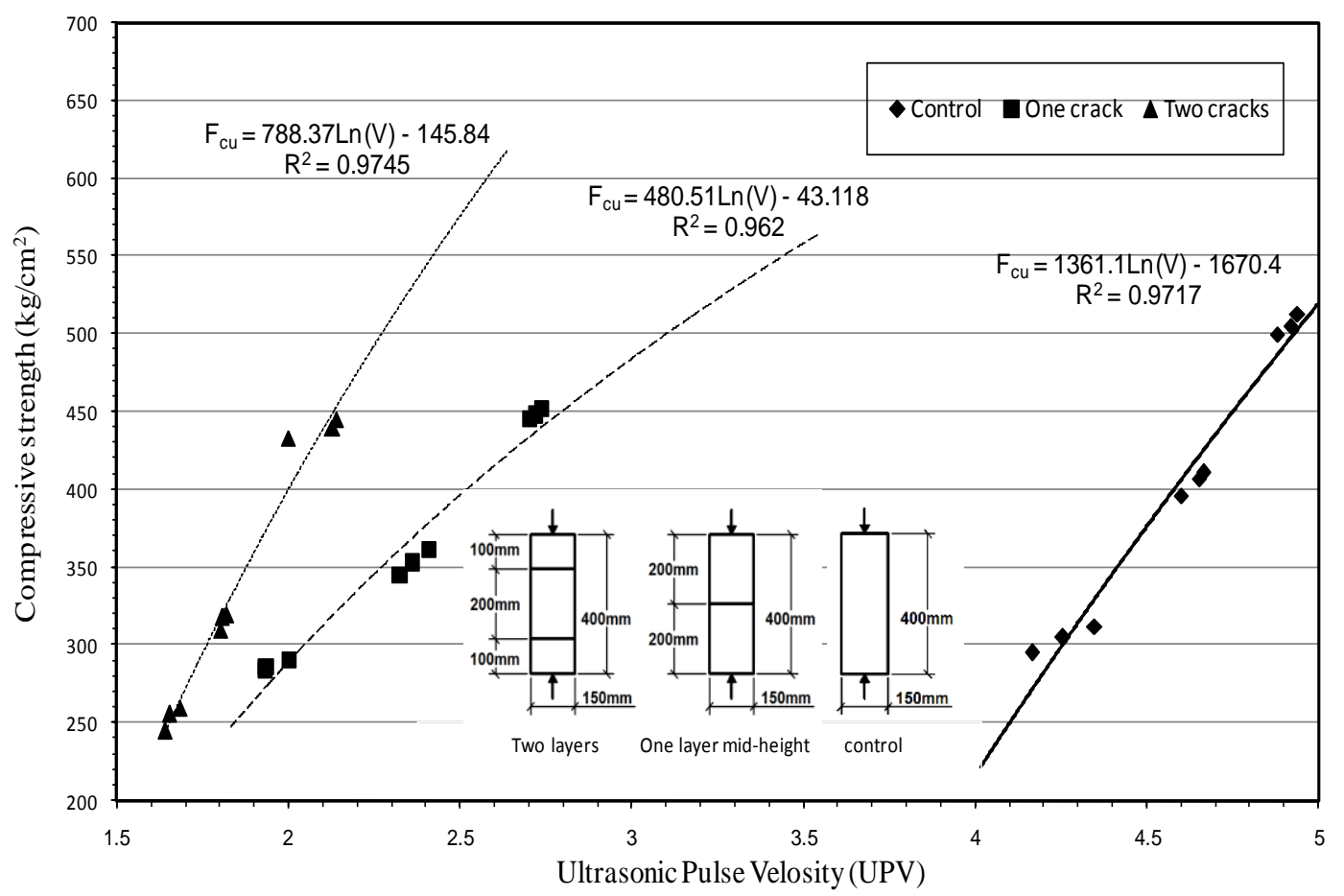

Fig. (13) Calibration curves for detecting compressive strength of SCC induced with horizontalcrackes by UPV device 


\subsection{Compressive Strengths of SCC Have Horizontal Construction Joint by UPV Device}

Figure (14) reported the results of compressive strengths by UPV device (direct method) for group 6 of SCC cast by stages (one and two construction joints) where the ages between each layer was 24 hours. Results indicated that fracture compressive strength of SCC with one separation was about $91 \%$ of the control SCC whereas SCC with two separations reached $86 \%$.

It is shown from Table (6) the reduction of compressive strengths for SCC cast with multi-layers may exist especially when a construction joint do not carried out perfectly according to the specification and rules of the concrete industry limitations. So, it is recommended that take care should taken into consideration for separation erection and it is recommended, if possible, to cast the construction with SCC in one time.

The compressive strength of SCC with multi-separations can be detected by UPV device correctly if calibration curves were prepared as indicated in Fig. (14) where Equations ( 5 and 6 ) represented the compressive strengths by UPV device for SCC with one ore two separations respectively are :

$$
\begin{aligned}
& F_{c u}=1386.4 \operatorname{Ln}(\mathrm{V})-1634.9 \\
& F_{c u}=601.5 \operatorname{Ln}(V)-1886
\end{aligned}
$$

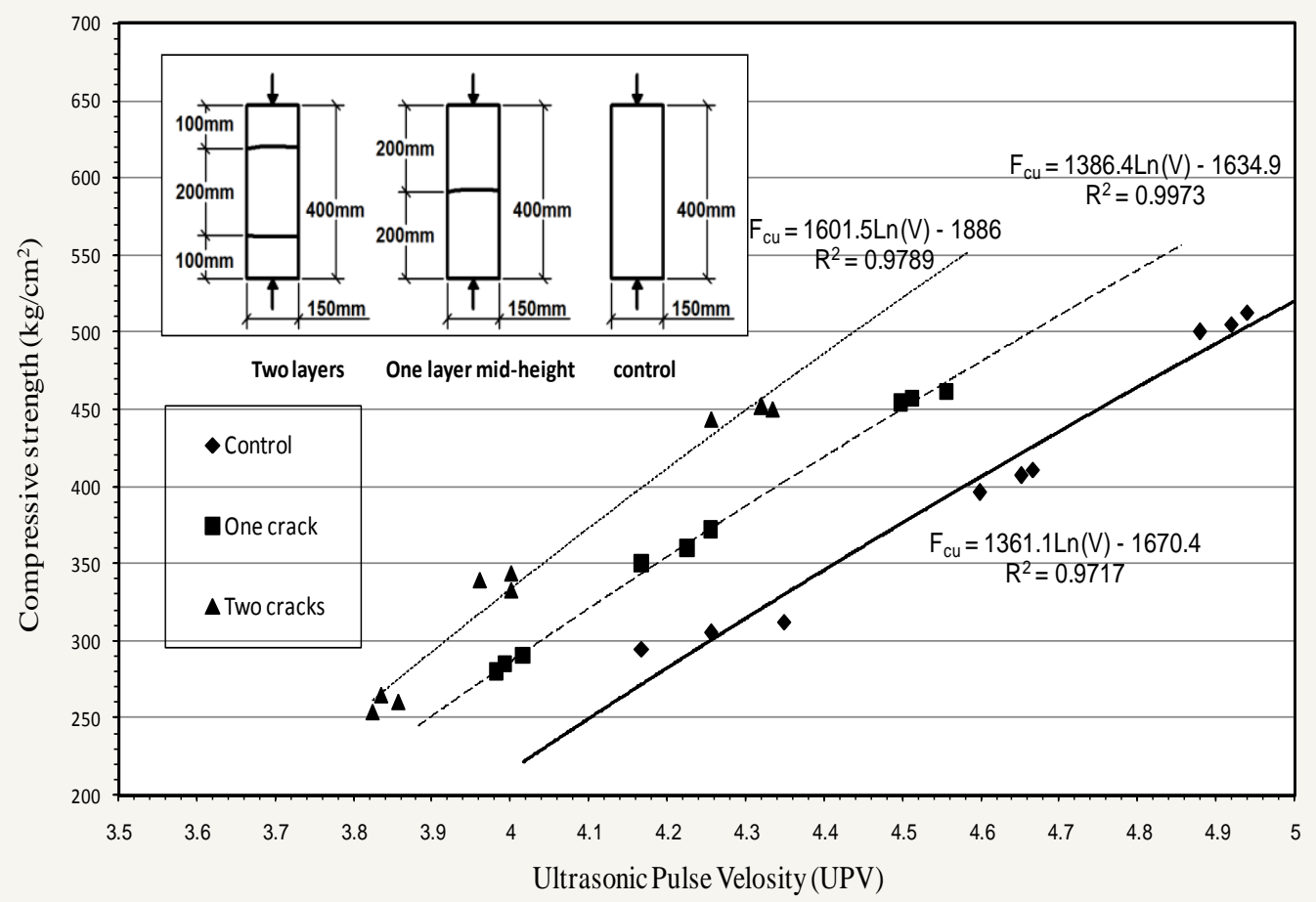

Fig. (14) Calibration curves for detecting compressive strength of SCC with horizontal crack joints by UPV device 


\section{CONCLUSIONS AND RECOMMENDATIONS}

The results of the experimental work on different SCC mixes and dimensions in order to investigate the effect of horizontal crack and compressive strengths of SCC with horizontal crack or construction joint have been considered in this research. On the sound of results obtained in this paper, the following conclusions can be drawn:

1- Horizontal of SCC can be detected by UPV device with limited distances of transmitter and receiver according to the crack position and case of measuring.

2- Limitations of the distances of receiver and transmitter should be taken into consideration as minimum distances $100 \mathrm{~mm}$ and reasonable distances (100-300 $\mathrm{mm}$ ) for the crack region.

3- Investigation can be detected easily if the UPV device was in the position of the crack such as case 1 with induced crack to edge and case 2 with induced crack depth to center in addition to case 3 with induced crack to center

4- Compressive strengths of cracked SCC by UPV was unrealistic and new calibration curves were carried out for cracked SCC and SCC with construction joints

5- Taking care should be taken into consideration for construction joint erection of SCC where a reduction of compressive strength of SCC was reduced by (9-14\%) whereas the reduction of compressive strength was about (10-17\%) for cracked SCC.

\section{ACKNOWLEDGEMENT}

The experimental work was carried out in the structure, material and concrete laboratories of civil, chemical and mechanical engineering departments of Mansoura University, EGYPT. All the academic and technical staff at the university is gratefully acknowledged.

\section{REFERENCES}

[1] Malhotra V. M. and Carino N. J., "Handbook on nondestructive testing of concrete", second edition, ASTM International, CRC press, Chapter 8, 2004.

[2] S. Ashok Kumar and M. Santhanam, "Detection of Concrete Damage Using Ultrasonic Pulse Velocity Method ", Indian Society for Non-Destructive Testing Hyderabad Chapter, Proc. National Seminar on Non-Destructive Evaluation, Dec. 7 - 9, 2006.

[3] Bungey J.H., Millard S.G.: Testing of concrete in structures, Blackie Academic \& Professional, Glasgow, 1996., 47-74

[4] Malhotra V.M., Carino N.J.: Handbook on Nondestructive testing of concrete, CRC PRESS, Boca Raton, London, New York, Washington, 2004.

[5] Aničić, D.: Testing of structures, Faculty of Civil Engineering, University of Osijek, Osijek, 2002. (available on Croatian)

[6] Moumouni Moussa, "Reliability in Interpreting Non-Destructive testing (NDT) Results of Concrete Structures, Master thesis, Faculty of Engineering, University of Technology, Malaysia 2006. 
[7] Rhazi, J. (2001). NDT in Civil Engineering: the Case of Concrete Bridge Dicks. (On-line), http://www.ndt.net/article/v06n05/rhazi.htm ,19 May 2005.

[8] McCann, D.M.\&Forde, M.C. (2001). Review of NDT methods in the assessment of concrete and masonry structures. (On line). http://www.top25.sciencedirect.com/journal_id=09638695, 18 May 2005.

[9] Rilem. (2004), TC INR: Interpretation Of NDT Results And Assessment Of RC Structures. (On line), http://www.rilem.org, 19 May 2005.

[10] Nazarian, Yuan and Tandon "Mechanistic Quality Management of Asphalt Concrete Layers with Seismic Methods", Journal:Journal of Testing and Evaluation, ASTM (2004).

[11] Nazarian, S., and Stokoe, K. H. II. 1986. Use of surface waves in pavement Evaluation. Transportation Research Record, No. 1070, pp 132-144.

[12] Phillips, C., Cascante, G., and Hutchinson, D. J., 2004. "Evaluation of Horizontal Homogeneity of Geomaterials with the Distance Analysis of Surface Waves, Canadian Geotechnical Journal (in Press).

[13] Phillips, C., Cascante, G., and Hutchinson, J. 2000. Assessment of the Spectral Analysis of Surface Waves Method for Detecting Underground Voids. Annual Symposium on the Application of Geophysics to Environmental and Engineering Problems, Arlington, Virginia, pp. 29-37.

[14] Phillips, C., Cascante, G., and Hutchinson, J. 2001. Numerical Simulation of Seismic Surface Waves. 54th Canadian Geotechnical Conference. Calgary, Alberta, September, pp. 1538-1545.

[15] M. W. Witczak, K. Kaloush, T. Pellinen, M. El-Basyouny, and H. Von Quintus, "Simple Performance Test for Superpave Mix Design", NCHRP Report 465, Transport Research Board, Washington D. C. -2002.

\section{الكثف عن الشروخ في الخرسانة ذاتية الدمك باستخدام الموجات فوق الصوتية}

تتجه أنظار العالم اليوم إلى استخدام الخرسانة ذاتية الدمك فى كثير من التطبيقات فى مجال التشييد و . من ثم ازدادت فى الآونة الأخيرة الكثير من الأبحاث لدراسة خواص هذه النوعية من الخرسانة و حل لكثير من الصعوبات التي تعترضها. ولما كان كثير من المنشآت يصعب صبها فى يوم واحد لكثرة كميات الخرسانة فإننا نلجأ للصب على أكثر من مرحلة مكونة فاصل أفقى أو أكثر من فواصل الصب مما تعرض الخرسانة لفواصل أفقية قد ينتج عنها عيوب أفقية قد تمتذ إلى شروخ مستقبلا. و حيث أن الأبحاث التى تتعرض لهذه النقطة تكاد تكون قليلة و لا تغطى هذه الدراسة فأصبح من الضرورى دراسة سلوك الخرسانة ذاتية الدمك فى ظل وجود هذه الفواصل و ذلك بدراسة عدد 30 كمرة من الخرسانة ذاتية الدمك تم فحصها بجهاز الموجات فوق الصوتية لاكتشاف الثروخ الأفقية و التى تم إدراجها عن طريق وضع طبقة بلاستيكية رقيقة أو طبقتين على أعماق مختلفة و أوضاع مختلفة من الكمرات بعدد 18 كمرة و تم الكثف عن هذه الثروخ المعروف أماكنها بالطربقة الغير مباشرة لجهاز الموجات فوق الصوتية. و من ناحية أخرى نم دراسة عدد 12 كمرات بدون وضع طبقات بلاسنيك و لكن تم عمل فاصل أو أكثر 
كفواصل صب طبيعية و تم دراستها عن طريق فحصها بجهاز الموجات فوق الصوتية بالطريقة المباشرة

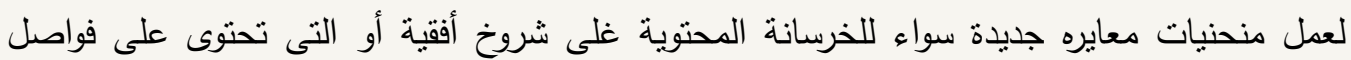

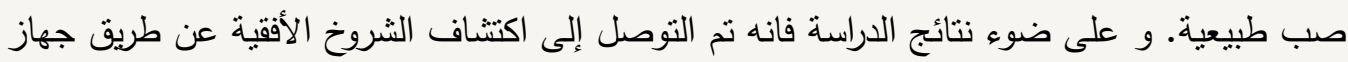
الموجات فوق الصوتية بالطريقة الغير مباشرة و لكن فى حدود مسافة معينة بين المرسل والمستقبل فد

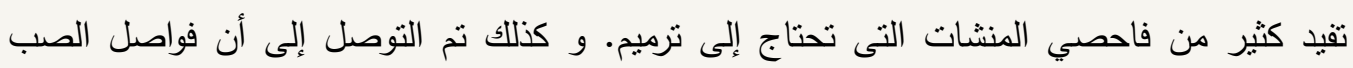

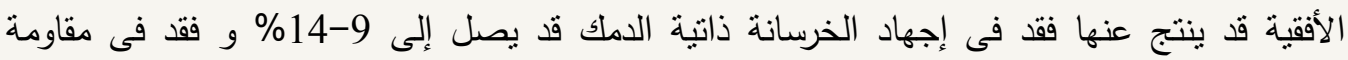

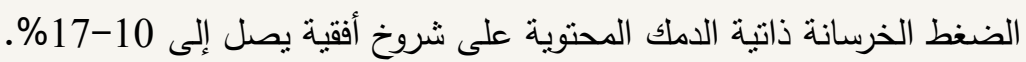

